Journal of World Englishes and Educational Practices (JWEEP)

ISSN: $2707-7586$

DOI: $10.32996 /$ jweep

Journal Homepage: www.al-kindipublisher.com/index.php/jweep

\title{
A Post-Colonial Re-Reading of Daniel Defoe's Robinson Crusoe
}

\author{
Dr. Hazmah Ali Al-Harshan \\ Assistant Professor at the Department of Languages and Translation, Faculty of Education and Arts, University of Tabuk, \\ Saudi Arabia
}

$\square$ Corresponding Author: Dr. Hazmah Ali Al-Harshan, E-mail: halhrshan@ut.edu.sa

\section{ARTICLE INFORMATION ABSTRACT}

Received: 08 October 2021

Accepted: 14 November 2021

Published: 23 December 2021

DOI: 10.32996/jweep.2021.3.12.3

\section{KEYWORDS}

Daniel Defoe, Colonialism, British subjectivity, Robinson Crusoe
The imperial project started to influence English national identity as early as the midseventeenth century, and the English began to relate their national prominence to their colonial activities, whether in trade or in the acquisition of foreign territories, throughout the eighteenth century. However, England experienced its share of anxieties on the road to imperial "greatness" in its dealings with both other European powers and its native subjects. The British people's tendency to examine themselves and their international achievements with intense pride helped to neutralize those anxieties, much like Crusoe's imagined responses to possible dangers alleviate his fictional forebodings. The English ameliorated their concerns about their international position by becoming an ever more self-referential society, thinking more highly of themselves on account of their contact with colonized peoples, as is epitomized in the personality of Crusoe. To the fictional Crusoe, the experience of his relationship with Friday validates his self-worth and his native culture more than anything else. Robinson Crusoe's affirmation of colonial power through the assertion of his authority over a particular (othered) individual corresponds with, and epitomizes, England's trading and territorial empire during the eighteenth century and the consequent effects on British subjectivity, at a time when the British were struggling to set up a trading empire and challenging other European powers for territory and markets abroad. Robinson Crusoe successfully resolves the insecurities relating to Britain's colonial activities by asserting, through Crusoe's character, the superior nature of the English subject.

Colonial discourse shapes Daniel Defoe's novel, Robinson Crusoe. Modern readers generally believe Defoe's novel to be the typical colonial novel of the eighteenth century. Brett Mcinelly argues that postcolonial study of Defoe's novel emerged, not in criticism, but in postcolonial literature such as Derek Wolcott's Pantomime and J. M. Coetzee's Foe, works that "write back" to Defoe's "master" narrative of empire. The Crusoe-Friday correlation "in postcolonial theoretical discourse" appears to summarize "the colonial myth and the dynamics of colonial relationships in general" (1-2). Meanwhile, in his seminal book, The Rise of the Novel (1957), lan Watt discusses Robinson Crusoe at length. He condenses the core of the novel form to its "formal realism", the "narrative method" by which novelists represent a "circumstantial view" of individual life (32). He considers Robinson Crusoe to be the first novel, specifically because of the detailed attention Defoe gives an "ordinary" individual. Watt, however, fails to consider the influence of colonialism on Crusoe's individualism. Brett Mcinelly posits that throughout "his journey toward selfhood ... Crusoe gradually learns how to assert himself over land and people. In short, the colonial setting facilitates Crusoe's individualism as he comes to recognize the unique place he occupies as a British Protestant in a world in which he is surrounded by religious and cultural Others" (2). Brett Mcinelly asserts that "Defoe, himself, likely acknowledged the distance between the reality of Britain's colonial endeavours and his representation," but we find it easy to believe that what he depicts in fiction is the actuality of Britain's activities. Mcinelly comes close to the point when he says that: "Defoe's debt to the colonial context takes place at the level of representing anticipations and premonitions of colonialism. Any influence he had on the colonial mentality is much more precisely

Copyright: (c) 2021 the Author(s). This article is an open access article distributed under the terms and conditions of the Creative Commons Attribution (CC-BY) 4.0 license (https://creativecommons.org/licenses/by/4.0/). Published by Al-Kindi Centre for Research and Development, London, United Kingdom. 
that [; it is] a mentality [rather] than a practice undertaken by actual agents in history. And the contribution of the colonial context to the history of the novel's similar vein" (4).

British national identity was shaped and concretized by the economic success enjoyed by the country during the eighteenth century, and Defoe himself associated global trade with national importance. Seven years after the publication of his first novel, he claimed, in The Complete English Tradesman: "We are not only a trading country, but the greatest trading country in the world" Colonies were vital to the nation's commercial success, and the significance of colonial markets to the local economy was obvious all through the century: therefore, Crusoe's achievements as a trader and colonizer may be regarded as a powerful and pertinent political statement. Crusoe, the typical colonizer, is an explicitly English colonizer. Martin Gliserman argues that "Robinson Crusoe sets up a new male hero, one that develops at the edge of the industrial period of capitalism and colonial expansion" (198). That is to say, he is neither aristocracy nor landed gentry, and he is neither a soldier nor a crown agent. His status is due to his success by his autonomous efforts.

Resembling the majority of his generation, Defoe believed that Britain's colonial activities were perfectly legitimate. In The Complete English Tradesman, he also maintains that:

We have not increased our power ... by subduing the nations, which possessed those countries and incorporating them into our own, but have entirely planted our colonies, and peopled the countries with our own subjects, natives of this island; and, excepting the negroes, which we have transported from Africa to America, as slaves to work in the sugar and tobacco plantations, all our colonies ... are entirely peopled from Great Britain and Ireland ... the natives having either removed farther up into the country or by their own folly and treachery raising war against us, been destroyed and cut off. (qtd. in Mcinelly 11, 13)

Defoe's comments reveal the attitudes of his contemporaries who associated British wealth with a rather peaceful empire based on supposedly free trade. Crusoe's island is deserted and later on populated by Europeans - the British mutineers and Spanish castaways - and a handful of 'converted' natives. It is, accordingly, an appropriate way for Defoe to illustrate Crusoe's activities as a relatively peaceful project. Undoubtedly the island symbolizes the prototypical pure English colony Defoe articulates in The Complete English Tradesman.

This paper tackles the theme of colonialism in Daniel Defoe's novel Robinson Crusoe from the perspective of postcolonial theory. In the field of postcolonial criticism, colonialism overtakes the straightforward procedure of conquering colonies. The main elements of "colonialist discourse are the concepts of racism and otherness." The "racial stereotype" was augmented and embellished through British colonial growth. The image of "the racial other colonized as inferior consolidated the identityformation of the colonizer as the superior self/master." The colonizer introduces hierarchical structures in the colonies based on race, gender, and class divisions and eradicates or subordinates the indigenous structures already present.

Therefore, the cultural mythology of origin symbolized Europe as autonomous, and the civilized European nations are seen to "discover" primitive peoples without civilization. This disparity provides a basis for discriminating between 'superior' and 'inferior' racial groups. As Abdelwahhab pertinently observes, "Racism and colonialism are therefore much associated to each other, since both are grounded upon the same logic of binarism" (Abdelwahhab 12-13- 14). Daniel Defoe's Robinson Crusoe remains central to the canon of postcolonialism because of its privileged literary position in the European tradition: the novel is widely judged to stand at the beginning of the traditional history of the English novel; it was published at the very beginning of Great Britain's rise as a colonial power. Edward Said begins Culture and Imperialism with this brief observation about the novel per se: "The prototypical modern realistic novel is Robinson Crusoe, and nor is it accidentally about a European who creates a fiefdom for himself on a distant, non-European island" (xii). J. A. Downie writes: "I would argue, Robinson Crusoe and Captain Singleton, as well as Moll Flanders and Captain Jack, involve imperialistic propaganda to promote his schemes for trade and colonization. That they do not nakedly state a thesis in favour of empire is a mark of the subtlety with which Defoe approaches the subject, not an argument against such an interpretation of his novels" (66). Brett Mcinelly also argues that "Robinson Crusoe cries out for study in its colonial contexts. Indeed, British colonialism informs nearly every feature of Daniel Defoe's first novel: spatially... religiously... economically, and psychologically.... In short, Robinson Crusoe, many of its most, owes characteristic trails to the colonial context" (1).

Re-reading Robinson Crusoe through the lens of colonial modification emphasizes that the text is about a fictional island colony arbitrarily claimed and incorporated into the British Empire. Each step of Crusoe's journey to his island shows that the novel is a means of colonial control. Maximillian Novak points out that, in Robinson Crusoe, Defoe deals with "colonialism through the power of fictional representation into the adventures of a single who masters an island, his native companion, and himself. His formal realism works to enfold the myths of psychological and economic self-sufficiency in a texture of convincing detail" (140). 
Crusoe's individualism represents one of the more remarkable features of Robinson Crusoe. In the first paragraph of Defoe's novel, the eponymous Crusoe describes himself as a character born into hybridity. His name, an important aspect of his identity, is already corrupted and revised:

I was born in the year 1632, in the city of York, of a good family, though not of that country, my father being a Foreigner of Bremen who settled first at Hull. He got a good estate by merchandise, and leaving off his Trade, lived afterwards at York; from whence he had married my mother, whose relations were named Robinson, a very good Family in that country, and from whom I was called Robinson Kreutznaer; but by the usual corruption of words in England we are now called, nay, we call ourselves and write our name Crusoe, and so my companions always called me. (25)

Defoe represents England as a courted or hybrid state that is associated with the growing slave trade in Africa. Crusoe establishes his identity as born to a foreign father, but he becomes English through his English mother and by the "the usual corruption of words in England." Within a few pages of this opening, Crusoe defies his parents and goes on a trading voyage to Guinea and another to Sallee. He follows the complex and growing Atlantic slave routes. By the end of his adventures, Crusoe is filled with a sense of his own importance. In Robinson Crusoe, we get a work that asserts the dominance of the individual human subject (though this requires the reader to ascribe humanity to only a portion of the human race). lan Watt attributes such individualism to the rise of capitalism and the spread of Protestantism. Meanwhile, Edward Said and other postcolonial critics have shown the profound influence of imperialism on Western culture and its arts. Implicit in Watt's argument is the idea that the kind of individualism we see in Robinson Crusoe could have only arisen in eighteenth-century England, a stronghold of Protestantism and material capitalism. Watt mentions the debt Robinson Crusoe owes seventeenth and eighteenth-century travel literature, and he suggests that colonialism helped to "assist" the "development of capitalism" (67), but his study goes no further in examining the influences of colonialism on the early novel.

Throughout Crusoe's journey to his island, his sense of self and place in the world is revealed. For example, Crusoe's early encounters with the Moorish master show his feeling of superiority over another race, in spite of his circumstances "at this surprising change of my circumstances, from a merchant to a miserable slave, I was perfectly overwhelmed" (42-43). When his master takes him to his home, Crusoe hopes that the master will take him to sea as a partner, but his wish is not fulfilled as he is obliged to "do the common drudgery of slaves.... [and] to lie in the cabin to look after the ship". Yet most of the time, he believes that the master is certain to be "taken by a Spanish or Portugal man-of-war and that then [he would] be set at liberty" (43). Moreover, Crusoe's treatment of his fellow slaves, Ishmael (Moley) and Xury, demonstrate his sense of being from a superior race. When he plans to escape from his Moorish master, he finds that it is easy to play a trick upon them. His behaviour is a frank allegory of British colonial conquest and power. Crusoe's tendency to imagine himself in over-exalted terms replicates something of what was occurring in the culture at large in the early eighteenth century: as Martin Green explains, "From 1688 on," "England had been expanding, and the pride of Englishness had been swelling, particularly with reference to the country's overseas possessions" (4).

When Crusoe's flight succeeds, he takes Xury as a servant: "Xury, if you will be faithful to me, l'll make you a great man, but if you will not stroke your face to be true to me ... I must throw you into the sea. The boy smiled in my face and spoke so innocently that I could not mistrust him; and swore to be faithful to me, and go all over the world with me" (47). Again, Crusoe's attitude exemplifies the British colonial subjection of others. Roxann Wheeler points out that "Crusoe's relationship to Xury has been interpreted typically as a relation of master to slave, and certainly Crusoe's selling Xury to the Portuguese captain confirms this idea" (381).

Defoe's misrepresentation of African people is also shown. We are also told that when they "were said on to the southward, to the truly barbarian coast", Crusoe feels the horror of being in a place "where whole nations of Negroes were sure to surround us with their canoes and destroy us; where we could never once go on shore, but we should be devoured by savage beasts, or more merciless savages of humankind" (48). Crusoe's mind vividly imagines the awful fate of being caught by Negroes: "for to have fallen into the hands of any of the savages, had been as bad as to have fallen into paws of lions and tigers" (50). Crusoe represents them as a cruel, brutish and primitive civilization. In his voyage towards the south of Africa, he sees " people stand upon the shore to look at us... quite black, and stark naked" and observes that he-"kept at a distance, but talked with them by signs... for something to eat"(54-55).

Crusoe's encounters with his first saviour, the Portuguese sea captain, are also indicative of elements in Crusoe's racially prejudiced character. Unlike his engagement with the Moorish captain, when Crusoe encounters the Portuguese ship, the Portuguese captain shows him humanity. Crusoe informs the reader that he "made [his] escape out of slavery from the moors at Sallee. They bade me come on board, and very kindly took me in, and all my goods" (58). Then, despite Xury's faithfulness and loyalty, Crusoe agrees to sell him into slavery because the Portuguese captain says he will "give the boy an obligation to set him 
free in ton years if he turns [s] Christian....". This is enough to quieten Crusoe's conscience. He concludes that "Upon this... I let the captain have him"(59). Once more, Crusoe's chauvinistic character is revealed. He cannot see any parallel between when he himself was made a slave (something which he could hardly believe possible) and selling another human being. Edward Said argues that Robinson Crusoe is "a work whose protagonist is the founder of a new world which he rules and reclaims for Christianity and England" (70). This agenda overrides any other person or nation's agenda and can be used as an excuse for any kind of imperialistic behaviour.

Crusoe exemplifies a subject who accommodates himself to the changing economic situation. Mcinelly argues that "Defoe's novel functions as an argument for the expansion of trade" (1). During the four years that Crusoe spends in the Brazils, he works in the plantation; he "[learns] the language... [andcontracts acquaintance and friendship among [his] fellow-planters, as well as among the merchants". We are told that he repeatedly gives them descriptions of his "two voyages to the coast of Guinea, [and] the manner of trading with the negroes there." Crusoe's fellow-planters and the merchants always listen and-very carefully to his accounts, in particular "to that part which relate[s] to buying negroes, which was a trade at that time." They privately intimate to Crusoe that they would like to fit out a ship to go to Guinea; that they had all plantations and desired to make but one journey, "to bring the negroes onshore privately, and divide them among their own plantations". They want Crusoe "to manage the trading part upon the coast of Guinea, and they offer him an equal share of the Negroes"(65-66). It is obvious that the novel involves imperialistic propaganda for colonization and trade.

Robinson Crusoe is a vehicle of the colonial imagination. After Crusoe's landing on the island, he proceeds to survey the country. Spying a very tall hill nearby, he does a difficult climb to better view his surroundings and finds "a proper place for [his] habitation...." The view from the hill is disconcerting but full of potential. The reader is told, "after I had with great labour and difficulty got to the top of the hill, I saw my fate to my great affliction, namely, that I was in an island environed every way with the sea"(82). Rebecca Weaver-Hightower describes this move to survey the islands as a common practice in colonial literature (201). As Crusoe describes the scene, there is stress on the barrenness of the island and accordingly on its availability to be 'inscribed' by Crusoe (British colonizer). In psychoanalytic theories of assimilation, this act of observation is a move to integrate the island into the body and the psyche of the colonizer. Crusoe attempts to domesticate the island, which hints at Crusoe's sense of well-being as a colonizer.

Crusoe, at times, refers to his home on the island and his defence as "my castle" $(198,210,238,262)$. This reference reveals the way in which Crusoe has actually colonized the island. On one occasion, he declares: "it would have made a stoic smile, to have seen me and my little family sit down to dinner: there was my majesty, the prince and lord of the whole island; I had the lives of all my subjects at absolute command; I could hang, draw, give life and liberty, and take it away, and no rebels among all my subjects. Then to see how like a king I dined too, all along one, attended by my servants"(191). It is proof of British power over the other. Robert Marzec argues that Robinson Crusoe represents the developing sensibilities of the Enclosure movement in early eighteenth-century Britain:

Daniel Defoe himself was a great believer in the power of enclosures to establish a radically new mode of enlightened (imperial) existence that transformed the land into an object to be mastered by humankind. In $\mathrm{A}$ Tour through the Whole Island of Great Britain, Defoe surveys the domain of England's immediate landscape, cataloguing in some six hundred pages every quarter of English soil. Throughout, he advocates the scientific and market-driven normalization of the land, valorizing enclosures as 'islands of improvement in a sea, of openfield (130).

Furthermore, the scene in which Crusoe finds the footprint, an unexpected mark or sign on the blank space of the shore, shows Crusoe's ability to possess the island. Indeed, after this incident, Crusoe sets about renewing his efforts at fortification, hiding his 'home', finding places for his goats and his wood. All of Crusoe's efforts at domestication and control move to protect his territory and his colony from the cannibals as he "had heard that the people of the Caribbean coasts were cannibals or maneaters... and that they might kill him, as many Europeans who had fallen into their hands" (163). We are told that he becomes "filled with thoughts about [his] danger from the appearance of savages" (201). He "is as fearful of seeing them as of seeing the devil himself... [he can] think of nothing but how [he] might destroy some of these monsters in their cruel, bloody entertainment, and ... save the victim they should bring hither to destroy" $(213,215)$. It can be argued that the true colonization of Crusoe's island begins after this incident. Eve Tavor points out that, "When Robinson does attack the cannibals, he does so as a governor responsible for the life, liberty and possessions of his subjects, whom he is defending against direct attack" (18). The protection and renewed efforts at domesticating the island eventually led to the salvation of Friday, the repopulation of the island by first Spaniards and then other castaways and eventually Crusoe's positioning of himself as a 'governor' of the island. 
Within a few pages of the scene of the footprint, Crusoe gives us an atrocious and ugly image of the natives as cannibals and man-eaters: "when I came down the hill to the shore... I was perfectly confounded and amazed...to express the horror of my mind, at seeing the shore spread with skulls, hands, feet, and other bones of human bodies... where I supposed the savage wretches had sat down to their inhuman feastings upon the bodies of their fellow-creatures." Then he comments: "all my apprehensions were buried in the thoughts of such a pitch of inhuman, hellish brutality, and the horror of the degeneracy of human nature" (209). Crusoe even experiences recurrent nightmares; anxiety continually afflicts his mind; he "often dreamed of killing the savages" (233). Crusoe's represents himself as the figure of the European man in the new world and his humanity and domineering relationship to a native. Selling people is wrong unless Crusoe is the person engaged in that business; killing people to eat is wrong but killing people as a punishment is justified if such actions are performed by an Englishman.

On seeing the natives' brutal feastings upon the bodies of their fellow-creatures, Crusoe's xenophobic character is shown. He comments, "this would justify the conduct of the Spaniards in all their barbarities practised in America, where they destroyed millions of these people, who, however, they were idolaters and barbarians, and had several bloody and barbarous rites in their customs - such as sacrificing human bodies to their idols - were yet, as to the Spaniards, very innocent people" (219). A disturbing obsession as a result of his encounter with the footprint colours Crusoe's narcissism. Mcinelly comments that Crusoe's response to the footprint accordingly "reveals how the ambivalence of colonial discourse, by fixing the colonized subject as a partial presence, can be inherently subversive. The footprint represents, quite literally, both a presence and an absence." For the first time since arriving on the island, Crusoe faces the possibility of encountering someone other than himself, "the prospect of which unsettles Crusoe's solipsistic state. Prior to this event, Crusoe has virtually no reason to reflect at length on anyone but himself, and the footprint forces him, for the first time, to contend with an image other and different from his own" (17-18).

Crusoe's picture of Friday's salvation and his renaming is harsh: "he stood trembling, as if he had been taken prisoner, and had just been to be killed, ... and he came nearer and nearer, kneeling down ... kissed the ground, and laid his head upon the ground, and, taking me by the foot, set my foot upon his head. This, it seems, was in token of swearing to be my slave forever" (245). On another occasion, we are told: "he came to me, laying himself down again upon the ground, with all the possible signs of a humble, thankful disposition ... he lays his head flat upon the ground, close to my foot, and sets my other foot upon his head as he had done before... he made all the signs to me of subjection, servitude, and submission imaginable." (256-257). This image of submission is memorable. Friday makes all the possible signs of slavery. Crusoe's description of Friday's salvation demolishes all the signs of human honour, respect and consideration. Anthony James maintains that Crouse's initial concerns are almost wholly how he can use Friday "to implement his dream of power and domination"(79).

It is worthy of note that Crusoe's accepts Friday's because he possesses different features from the native inhabitants; he is not a Negro. We are told that Friday:

was a comely, handsome fellow, perfectly well made, with straight, long limbs, not too large, tall, and wellshaped, and about twenty-six years of age. He had a very good countenance, not a fierce and surly aspect, but seemed to have something very manly in his face, and yet he had all the sweetness and softness of a European in his countenance... his hair was long and black, not curled like wool; his forehead very high and large, and a great vivacity and sparkling sharpness in his eyes. The colour of his skin was not quite black... but of a bright kind of a dun olive colour, that had in it something very agreeable... His face was round and plump, his nose small, not flat like the Negroes, a very good mouth, thin lips, and his teeth fine, well set (258).

Crusoe's racially prejudiced character is exposed obviously. He renames the 'Cannibal' he saves 'Friday' and himself, 'Master': "[i]n a little time I began to speak to him, and teach him to speak to me; and, first, I made him know his name should be Friday, which was the day I saved his life ... I likewise taught him to say Master, and then let him know that was to be my name" (257). Clearly, Crusoe emphasizes the hierarchy that will be observed on an island he can claim as 'his.' But it is important to note that the name Crusoe chooses in "Master", a name that clearly signifies his authority over Friday.

Deficient in language, Friday depends on every possible 'gesture' or bodily sign of slavery to express his place in relationship to Crusoe. In fact, Crusoe immediately begins to teach Friday a variety of common nouns: "I likewise taught him to say Yes and No, and to know the meaning of them" (257). Crusoe's attempt to re-master the language of his colonial island conforms with the ways of colonialism. Just as Defoe transforms colonialism through representation, Crusoe refashions himself and the island through imagination and language. Novak argues that Crusoe "transforms his island world through the agency of language, and particularly ... through a creative process of naming" (110). In making laws and giving names to places and things on the island, including himself, Crusoe both creates and assumes control over his island home. "By renaming [Friday]," Novak states, "Crusoe assumes possession of him in the same way that Columbus assumed possession of the land by his naming" (117). Novak sees the act of naming as a means of taking possession of Friday. Like Defoe's novel, Crusoe's tendency to imagine and create through language 
his own reality reveals something of the nature of colonialism in general that it involves an assembly of images and cultural constructs, as well as material practices and circumstances.

The idea of the colonial self-possessed of the canalized people can be seen in the "Parrot" incident. When Crusoe returns from a tour around the island, he falls into a deep sleep only to be awakened by a voice, "calling me by my name several times, Robin, Robin, Robin Crusoe, poor Robin Crusoe, where are you Robin Crusoe, where are you? Where have you been?" Waking up, he finds that it is only his old Parrot, repeating his lessons, "for it was in just such bemoaning language I had used to talk to him and to teach him" (185). The Parrot becomes an echo for Crusoe's own voice. David Medalie opines that "Crusoe's response to his circumstances is to institute "a pristine patriarchy of his own on the Island, whereby he subjects all those creatures who come under his power to a fatherly yet firm control as he establishes hierarchy and authority" (44). The Parrot's mimicking of Crusoe's words within the text is very significant. It may be read as symbolic of the colonial re-formulation of the native tongue. The colonized mimic the colonizer's language. From a postcolonial perspective, the "parrot" scene seems to reflect Homi Bhabha's analysis of mimicry. He argues that in mimicking the colonizer's language, the colonial subject presents a discourse that is notably "almost the same but not quite" (89). He is right - for how can the colonized and the colonizer see the world from the same perspective?

Ironically, Crusoe's desire for a servant is another manifestation of his narcissism. In re-creating Friday, Crusoe actually prolongs his isolation on the island' Friday speaks Crusoe's words and imitates his actions; he is a mere extension of Crusoe himself. In this regard, Friday is not unlike Crusoe's pet parrot, who learns to repeat Crusoe's words and even parrots back his own thoughts. Friday is always Other, and Crusoe maintains the master-slave paradigm that underlies their relationship. Friday is thus the perfect companion for Crusoe: he provides a mirror image of Crusoe's character while at the same time reinforcing his authority. His almost perfect mimicry of Crusoe reinforces Crusoe's belief in the superiority of his religion, culture, and social and political values. Moreover, Friday reflects back to Crusoe the image of a compassionate colonizer, thus firmly establishing Crusoe's authority on the island.

After articulating both of their new names, Crusoe shows Friday first his milk, then his earthen pot and finally his bread: "I gave him some milk... and let him see me drink it before him, and sop my bread in it, and I gave him a cake of bread to do like.... And let him know I would give him some clothes, at which he seemed very glad, for he was stark naked" (257). When Friday signs to Crusoe of his inclination to eat the flesh of a human being, we are told that Crusoe becomes very angry, expresses his loathing of it, made as if he would vomit at the thoughts of it. Once, Crusoe says, "I found Friday had still a hankering stomach after some of the flesh and was still a cannibal in his nature, but I discovered so much abhorrence at the very thought of it, and at the least appearance of it, that he durst not discover it; for I had, by some means, let him know I would kill him if he offered it" (258). Therefore, Crusoe "thought, that in order to bring Friday off from his horrid way of feeding, and from the relish of a cannibal's stomach. I ought to let him taste other flesh" (262). After indicating to Friday the signs of his mastery over craft, Crusoe demonstrates the power of his gun. Crusoe kills a kid goat lying next to his mother and a parrot. Through Friday, Crusoe begins to establish himself as someone who is not defeated. His ability to affirm himself as a teacher, in this case, also testifies to his ability to master the island. Mcinelly states: "psychologically, Robinson Crusoe shows that relations with an alien other can hone an ego that can master both its own selfhood and the destiny of others" (1).

The colonial context can be also read into Crusoe's attempt to convert Friday-from his tribal religion to Protestant Christianity. Timothy Blackburn suggests that Crusoe is "more concerned about being the agent of Friday's conversion" than he is in the conversion itself - as he was about "being the agent of Xury's conversion early in the book." Blackburn also observes that Crusoe "does cause the conversion of Xury, who clearly "foreshadows' Friday" (368). Demonstrably, the British saw themselves as saving native peoples from Catholicism as well as from their own 'savage' ways.

Crusoe explains that "[d]uring a long time that Friday had now been with me and that he began to speak to me, and understand me, I wanted to lay a foundation of religious knowledge in his mind; particularly I asked him one time, Who made him? The poor creature did not understand me at all". Thus, Crusoe begins to instruct him in the knowledge of the true God and Friday "listen[s] with great attention, and receive[s] with pleasure the notion of Jesus Christ being sent to redeem us" (268). Subsequently, Crusoe reports that "the savage was now a good Christian, a much better than I"(273). We come to realize that in the figure of Friday, Defoe depicts the price of colonization. However, the religious overtones of Defoe's text provide an outline for a religiously 'sound' colonial policy. Colonialism must, as does Crusoe, establish a strong, liberal, and principled policy on religion. Native populations are to be gently encouraged, not compelled, to accept Christianity. Mcinelly argues that "[r]eligiously, the novel demonstrates that a spiritual awakening can take place in isolation from society and can be crystallized when an English subordinates and converts a non- European other" (1). 
In addition to referring to himself as "Master", Crusoe also calls himself Friday's father and initially expresses keen jealousy over Friday's joy at reuniting with his own father. Crusoe refers to Friday in many different ways: "faithful, loving, sincere servant" (260), "poor savage" (201), "poor, honest Creature" (258), "my Companion of all my sorrows and solitudes" (269), "Christian" (273), "my Man Friday", (282), "the poor... Creature" (294). Crusoe takes great pains to show Friday's submissive and tireless affection for himself. Srinivas Aravamudan argues that the multiplicity of contradictory labels for Friday demonstrates Crusoe's difficulty in finding a suitable category for him. Is he a slave or a son, a companion or a savage? But this variety of labels points to the difficulty of defining Friday's identity and expresses Crusoe's desire for colonial mastery (26).

The strange absence of women in Robinson Crusoe may relate to the issue of colonialism itself. Individualism, colonization of supposed inferior countries, the imposition of the imperial culture - these were deemed to be the attributes and capabilities of men, not women. Women are at the margins throughout the novel, where they appear at all: they comprise Crusoe's mother, the widow who manages his money, the native women who marry the Spanish colonizers, and finally Crusoe's wife. On the other hand, reading 'masculinity' in the novel reaffirms the patriarchal structures of Crusoe's island. Women characters draw the patriarchal line and support male heredity throughout the novel. lan Bell argues that the women who do appear, even briefly, in Robinson Crusoe are important because they represent stability and orderliness (29). What is remarkable about the native women in Robinson Crusoe is the fact that they become followers as opposed to leaders in the colonization of the island. When their marriages are legitimized, they become almost Englishwomen, and their children populate the island.

Robinson Crusoe represents in its pages an absence of male sexuality. Robyn Wiegman argues that Defoe's novel represents the epitome of male sexual behaviour. According to Wiegman, sexuality is expressed through images of economic production and mastery over the empty island and the "native" Friday (34). From a postcolonial perspective, the conquered colonial landscape is often represented as a sexualized foreign female body. Conquering the virginal landscape is, therefore, a metaphor for conquering land and its fruits.

As a model of colonial development and wealth, the island is a colony. Crusoe declares: "I never so much as gave the place a name, but left it, as I found it, belonging to nobody, and the people under no discipline or government but my own; who, though I had influence over them as a father and benefactor, had no authority or power to act or command one way or other" (330). Arguably, one can read this statement as an expression of Defoe's desire to have the British government step in to establish colonies in this region. "By the? Novel's end," Susan Maher maintains ", Crusoe calls himself 'governour' of 'my island'; that he? Survives twenty-eight years beyond the margins of culture only to return a successful colonizer bespeaks the underlying power of his myth" (34).

While Friday, then, remains a powerful image in Robinson Crusoe, he is in some sense another symbol of the island. The island is transformed in Defoe's text from a place of despair to a colony to a refuge. Crusoe's island is a location for a mish-mash of cultures: Spanish, English, Portuguese, "cannibals", and Catholic. He calls it "my colony" and only leaves the island after drawing up a contract with the new inhabitants: "I shar'd the Island into Parts with 'em, resery'd to myself the property of the whole, but gave them such parts respectively as they agreed on, and having settled all things with them, and engaged them not to leave the Place, I left them there". But in addition to dividing the island, Crusoe gives the new inhabitants his narrative, "I gave them every part of my own Story" (335). As we see in the novel, Crusoe's efforts are rendered meaningless as the inhabitants' battle with one another to construct their own contracts with one another.

In his first adventure outside the island, Crusoe moves to another island, one that seems like a mirror for his own 'colony'. Its name is Madagascar. Like Crusoe's island, "native" women and children populate it. However, Crusoe explains the rape of a native girl by an Englishman. When the Englishman is killed by the girl's people, the men from Crusoe's team go to take revenge. They burn down all the houses of the local village and kill hundreds of the villagers, men, women and children. This "battle" in Madagascar provides a harsh contrast with the (at least initial) peacefulness of Crusoe's island. Crusoe describes his own horror at the violence done by the Englishmen; he also compares the killing to the battle of Drogheda, in Ireland or that at Magdeburg, in Germany. Defoe thus elevates the slaughter at the village to the same level as historically-documented battles in Europe. In so doing, he humanizes the victims of the colonial project. Moreover, these crimes indicate the consequences of colonialism. The horror of colonial violence, however, is represented as apolitical.

This problem of representing violence is an issue Crusoe returns to throughout the novel, beginning with the cannibalism and the fragments of bodies he finds on his island, moving through the confrontation with the natives, the battle at Madagascar, and finally ending with his deeply disturbing reflections. Here Crusoe will argue that although the battle of 'native' Americans by the Spanish seems cruel, this violence is undoubtedly the will of God: "It seems to me that Heaven had determined such an act of vengeance should be executed, and of which the Spaniards were instruments, to destroy those people, who had come up ... in that abhorred custom of human sacrifices" (219). Even as Defoe attempts to display the violence of policy, he also uses accusations of cannibalism to justify colonialism. 
While Crusoe attempts to "settle down" back in England, the island colony keeps on bothering Crusoe. He feels the deep longing to come back to his "colony":

For my part, I know not to this hour, whether there are any such things as real apparitions, spectres, or Walking of People after they are dead ... But brought me into such ecstasies of Vapors, or what else I may call it, that I actually supposed myself oftentimes upon the Spot, at my old castle, behind the trees. (363)

This moment of haunting evokes a comforting and restless nostalgia that takes him back to his colonial island. He describes himself as deoply divided between his desire to be at home with his wife and his desire to visit his island. Nonetheless, the intense desire for the island haunts Crusoe throughout the story. It gives a justification for Crusoe's decision to leave England and begin a life of quest again. Crusoe's decision to wander the world and the presence of the island raises questions for thinking of the colonial project. In his ability to move freely in the world, Crusoe makes obvious the simplicity of the possible British colonizer and the emergent of the colonial nation. So his mastery of the island is complete; he possesses the island and what it means.

Robinson Crusoe, therefore, has come to symbolize in lan Watt's word the "modem myth of individualism." lan Watt has labelled Robinson Crusoe as "The articulate spokesman of the new economic, religious and social attitudes that succeeded the counter-reformation" and a predictor of "those practical heroes, the empire builders"(xv). Watt argues that the appeal of Crusoe lies in his ability to represent the paradox of modern individualism. He is a self-sufficient capitalist individual, but this independence also represents a tragic dissolving from familial and community ties. Crusoe calls his decision to disobey his father and leave home his original sin'. But his ultimate success also depends upon this sin. Watt writes, "the original sin is really the dynamic tendency of capitalism itself whose aim is never merely to maintain the status quo but to transform it in incessantly"(65).

In conclusion, the novel presents a modern vision of the separated individual attempting to find a way to be at home in the world, but this fantasy of being at home in the world also relies on the colonial fantasy of conquering empty spaces and savaged nations. Crusoe's obsession with ordering and civilizing the world, which is the island, around him becomes representative of the British colonial project abroad. In fact, Crusoe's individualism is an intricate reality. Imperialism contributed suggestively to the construction of the individual (British) subject. Individualism and imperialism have a mutual relationship, the rise of each underpinning the other. British society became in the wake of an expanding empire. Arguably, the colonized world had a profound impact on British consciousness. The colonial framework against which the British defined themselves became subsequently adapted in later novels of the nineteenth century. Clearly, colonial space and the colonized Other are referred to as the structure of most British novels of that era.

\section{References}

[1] Abdel W, and Ahmed G. E. (2003). Colonialism and postcolonialism in Selected Works by Burgess, Conrad and Naipaul. Diss. The University of Ain Shams.

[2] Aravamudan, S. (1999). Tropicopolitans: Colonialism and Agency, 1688-184. Durham Duke University Press.

[3] Bell, I. (1996). Crusoe's Women: Or the Curious Incident of the Dog in the Night-time. Robinson Crusoe: Myths and Metamorphoses. Eds. Lievespaas and Brian Stimpson. New York: St. Martin's Press.

[4] Bhabha, H. (1985). The Location of Culture. London: Routledge, 1994. Blackburn, Timothy C. "Friday's Religion: Its Nature and Importance in Robinson Crusoe. Eighteenth-Century Studies. 18, no. 3: 360-82.

[5] Downie, J.A. (1983). Defoe, Imperialism and Travel Books Reconsidered." Yearbook of English Studies. 1:66-83.

[6] Defoe, D and Robinson C. (1972). Ed. Ramses Awad. Cairo: Anglo-Egyptian Bookshop.

[7] Gliserman, M. (1990). Robinson Crusoe: The Vicissitudes of Greed-Cannibalism and Capitalism. Displaced Desire: Money, Mother, Eating, and Encirclements. American Imago. 47:197-231.

[8] Green, M. (1990). Robinson Crusoe story. University Park: Pennsylvania State University Press.

[9] James, E A. (1972). Daniel Defoe's Many Voices. A Rhetorical Study of Prose Style and Literary Method. Rodopi NV: Amsterdam.

[10] Maher, S. N. (1991). Confronting Authority: J.M. Coetzee's Foe and the Remaking of Robinson Crusoe. The International Fiction Review.18: 34-40.

[11] Marzec, R. (2002). Enclosures, Colonization, and the Robinson Crusoe Syndrome: A Genealogy of Land in a Global Context. Boundary 2- An International Journal of Literature \& Culture. 29:129-59.

[12] Mcinelly, B. (2003). Expanding Empires, Expanding Selves: Colonialism, the Novel, and Robinson Crusoe. Studies in the Novel. 35 (Spring 2003): 1-21

[13] Medalie, D. (1997). Friday updated: Robinson Crusoe as sub-text in Gordimer's July's people and Coetzee's foe. Current Writing: Text and Reception in Southern Africa, 9(1), 43-54

[14] Novak, M. E. (2003). Daniel Defoe: Master of Fictions: His Life and Ideas. Oxford University Press on Demand.

[15] Said, E. (1993). Orientalism. New York: Vintage.. 1993. Culture and Imperialism. New York: Knopf, 10, 11-12.

[16] Tavor, E. (1987). Scepticism, Society and The eighteenth-Century Novel. London: The Macmillan Press.

[17] Waeaver-Hightower, R. (2002). Decolonization of the Island Mind: Counter - Discourse and postcolonial revision. ELH 28:

[18] Watt, I. (1957). The Rise of the Novel. Berkeley: University of California Press, 1957.

[19] Wheeler, R. (1995). My Savage', 'My Man: Racial Multiplicity in Robinson Crusoe. ELH 62: 821-61.

[20] Wiegman, R (1989). Economies of the Body: Gendered Sites in Wiegman and Roxana. Criticism--- A Quarterly for Literature and Arts. $31: 33-51$. 